\title{
Arab Spring: Islam dalam gerakan sosial dan demokrasi Timur Tengah
}

\section{Arab Spring: Islam within social movement and democracy in Middle East}

\author{
Shafira Elnanda Yasmine \\ Departemen Hubungan Internasional, Fakultas Ilmu Sosial dan Ilmu Politik \\ Universitas Airlangga, Surabaya \\ Jalan Airlangga 4-6 Surabaya 60286, Indonesia \\ Phone: +62 315011744 \\ E-mail: yasmineshafira94@gmail.com
}

\begin{abstract}
Social movement during Arab Spring has lead to political uprising in Middle East. Started from Tunisia, the revolt spread to neighboring states such as Egypt, Libya, also Syiria. Influenced by religion and strong Islamic tradition, protestors demand the presence of democracy within political system which had held autocracy as ruling system for decades. It is commonly assumed that democracy and Islam were mostly incompatible, moreover in a state whose Islamic values has deeply rooted in the daily life of its people. This article focuses in the usage of Islamic values within global civil society movement in Arab Spring. Theory of Islam and Ideology were applied to analyze the phenomena. Having view the revolution generally, this research found that Arab Spring is required as a phase which led Islam into particular flexibility level towards democracy and brought democratization into the Arab world. This article resulted in the conclusion that trigger a revolution not because of religious affairs, the demonstrators were joined not one hundred percent Muslim, and the issues that required not related to the religious life of the community, but Islam is either the value or the practice of worship, can not be separated in the organization of the masses during the revolution.
\end{abstract}

Keywords: Arab Spring, Islam, democracy, social movement

\begin{abstract}
Abstrak
Gerakan sosial yang hadir selama Arab Spring telah menimbulkan pergolakan politik negara-negara Timur Tengah. Dimulai dari Tunisia, revolusi tersebar pada negara tetangga yakni Mesir, Libya, juga Syiria. Hadir ditengah agama dan kultur Islam yang menonjol, tujuan revolusi adalah untuk menghadirkan demokrasi dalam sistem pemerintahan negara-negara yang telah lama berada dalam sistem autokrasi, namun selama ini demokrasi dengan Islam kerap dianggap tidak kompatibel satu sama lain, terutama di negara-negara dengan nilai-nilai Islam yang mengakar. Artikel ini berfokus pada penggunaan nilai-nilai Islam dalam gerakan masyarakat sipil global yang terjadi dalam Arab Spring. Meninjau revolusi secara makro, argumen utama penulis adalah bahwa Arab Spring menjadi sebuah fase yang mengantarkan Islam tingkat fleksibilitas tertentu terhadap demokrasi dan membawa demokrasi pada dunia Arab. Artikel ini menghasilkan simpulan bahwa pemicu revolusi bukan karena urusan keagamaan, demonstran yang bergabung tidaklah seratus persen kaum muslim, dan isu yang dituntut tidak berkaitan dengan kehidupan beragama masyarakat, namun Islam baik nilai atau praktik ibadahnya, tidak dapat dipisahkan dalam pengorganisasian massa selama revolusi terjadi.
\end{abstract}

Kata kunci: Arab Spring, Islam, demokrasi, gerakan sosial 


\section{Pendahuluan}

Peristiwa bakar diri Mohammer Bouzaizi, seorang pedagang buah Tunisia, di depan pengadilan Kantor Dewan Regional Sidi Bouzid memantik gelombang demokrasi terbesar yang pernah ada di Timur Tengah. Selama berbulan-bulan, demonstran menuntut diakhirinya rezim yang telah lama memerintah dan dianggap korup. Protes yang masih terus berlangsung hingga saat ini di beberapa negara terus menantang perspektif Barat terhadap Timur Tengah. Gerakan sosial yang hadir dalam revolusi ini berkaitan erat dengan hadirnya nilai-nilai agama. Kelompok-kelompok Islam di Timur Tengah memasukkan nilai-nilai kepercayaan, ritual, dan praktik-pratik agama dalam menjalankan revolusi dalam satu wadah gerakan sosial. Banyak pendapat mengenai hubungan antara agama dan politik dalam Arab Spring. Di satu sisi, Arab Spring hadir sebagai fenomena yang digerakkan oleh kelompok liberal sekuler yang menginginkan demokrasi, bukan teokrasi. Di sisi lain, kelompok demostran berkumpul di pusat-pusat keramaian, menuntut turunnya rezim yang berkuasa, dengan ceramah-ceramah agama sebagai motivasi dan masjid sebagai lokasi berkumpul para demonstran sebelum turun ke jalan. Di awal 2011, protes dan kerusuhan berkembang hingga hampir ke seluruh negara Arab. Protes yang terjadi bersifat 'lintas batas', bahkan partisipan yang terlibat berasal dari bermacam ideologi. Mobilisasi regional tidak lagi diarahkan untuk melawan musuh eksternal seperti Israel atau Amerika Serikat, melainkan untuk menyuarakan keprihatinan atas situasi di Arab sendiri, menciptakan solidaritas tersendiri dari berbagai kalangan. Ribuan demonstran tewas dalam memperjuangkan jatuhnya pemerintahan autokratis akan jatuh bagai domino. Artikel ini berusaha menjelaskan peranan agama dalam protes di Arab yang diturunkan melalui gerakan sosial. Meninjau latar permasalahan yang telah dipaparkan, artikel ini berusaha menjawab pertanyaan mengenai bagaimana nilai-nilai Islam disertakan dalam organisasi gerakan sosial di Timur Tengah? Sejauh apa Islam menjadi salah satu proses yang membentuk solidaritas gerakan sosial dalam revolusi Arab? Serta bagaimana gerakan-gerakan ini menjawab keraguan kelompok Barat atas kompabilitas Islam dengan demokrasi?

\section{Metode Penelitian}

Penelitian ini adalah tipe penelitian deskriptif yang menggunakan literatur untuk mendapatkan data, dan kemudian dianalisis berdasarkan landasan teori yang digunakan untuk membingkai data yang dianalisis. Landasan teoritik yang digunakan adalah agama dan perilaku, serta Islamisme dan gerakan sosial.

\section{Agama dan Perilaku Politik}

Agama dapat menjadi salah satu faktor yang memotivasi dan menyatukan demonstran. Kesepahaman dalam agama dapat mengurangi risiko yang timbul karena aksi kolektif yang dijalankan karena meningkatnya kepercayaan individu dengan anggota lain dalam gerakan sosial. Praktik-praktik agama komunal menjadi media yang lebih mudah dibandingkan perilaku individual untuk mempromosikan tuntutan dalam aksi protes karena mekanisme dalam agama merupakan modal sosial untuk mengorganisasi suatu gerakan (Hoffman \& Jamal 2013:6). Untuk memperbanyak modal sosial ini, kelompok agama komunal menjadi organisator penting dalam membentuk perilaku politik suatu kelompok. Johnston \& Figa (1998:33) menyatakan bahwa terdapat banyak varian mengenai bagaimana agama memainkan peranan dalam proses-proses oposisi. Perbedaan tersebut diungkapkan pula oleh Durkheim yang membedakan "kepercayaan" dan "ritual" dengan menuliskan bahwa fenomena agama secara alamiah terbagi dalam dua kategori: kepercayaan dan ritual. Kepercayaan mengandung opini dan keterwakilan, sementara ritual adalah aksi-aski yang dijalankan dalam kepercayaan tertentu. Loveland (dalam Hoffman \& Jamal 2013:6) juga menemukan bahwa doa mempercepat koneksi kognitif terhadap kebutuhan seseorang yang kemudian dimanifestasikan dalam pilihan-pilihan yang bersifat religius. Agama, karenanya, berpengaruh besar terhadap mobilisasi politik dan perilaku protes dalam berbagai cara dengan melalui berbagai jalan.

Jalan yang dilalui agama dalam menggerakkan kelompok dapat diklasifikasikan sebagai berikut. Pertama, agama menghadirkan modal sosial dan kepercayaan, yang dapat mengurangi risiko yang mungkin ditimbulkan dalam penyelenggaraan aksi bersama. Institusi agama memenuhi kebutuhan 
akan modal sosial tersebut. Religiusitas individu bisa menjadi nilai tambah dalam meningkatkan kepercayaan kelompok terhadap aksi kolektif yang dijalankan. Kedua, mekanisme yang dijalankan melibatkan pula mobilisasi politik, "dari Masjid menuju Lapangan". Masjid menjadi kendaraan untuk mobilisasi politik karena: tidak hanya Masjid menciptakan struktur partisipasi, namun juga melengkapi partisipan dengan kebutuhan-kebutuhan organiasional untuk turut berpartisipasi dalam aksi kolektif. Terakhir, agama menyediakan mekanisme keadilan sosial dan menciptakan kepatuhan bagi individu mengenai konsep keadilan dan kesetaraan (Durkheim dalam Hoffman \& Jamal 2013:8).

\section{Islamisme dan gerakan sosial}

Islam menjadi bagian dari gerakan sosial melalui ideologi (Hatem 2012:6). Hal ini dikenal dengan Islamisme. Islamisme adalah fenomena modern dalam kelompok Islam di seluruh dunia yang menggambarkan ekspresi politik dan sosial yang tujuannya adalah untuk mengintegrasikan Islam dalam politik, urusan negara, ekonomi, dan hukum (Chamki 2013:4). Definisi paling akurat disampaikan oleh Mohammad Ayoob yang menjelaskan Islamisme sebagai instrumentalisasi Islam oleh individu, kelompok, maupun organisasi untuk mencapai tujuan-tujuan politik. Politik Islam menjadikan Islam lebih dipandang sebagai politik ideologi kontemporer daripada sebagai agama atau teologi. Revolusi Arab menggambarkan bagaimana Islam menjadi lebih berpengaruh dari sebelumnya. Kelompok reformasi turut mengajak individu-individu yang sering terlibat dalam gerakan-gerakan islam sebelumnya, mengintegrasikan mereka dalam satu gerakan sosial baru yang menginginkan kehadiran demokrasi, keadilan sosial, dan kebebasan.

Di Timur Tengah, Islam sendiri menjadi bagian dari kehidupan masyarakat. Asef Bayat menekankan konsep aktivisme agama sebagai dasar untuk memahami bagaimana Islam menjadi dasar sebuah gerakan sosial. Aktivisme adalah praktik atau perilaku yang tidak biasa, dilakukan secara kolektif atau individu, secara institusional atau formal, untuk menyebabkan perubahan sosial. Terminologi tersebut menggambarkan fenomena yang selaras dengan perilaku aktif yang berlandaskan dasar-dasar agama. Islam, dalam hal ini menjadi aktivisme Islam, menggambarkan bagaimana perilaku tidak biasa diciptakan oleh kelompok Muslim di era modern. Politik bisa menjadi salah satu aspek yang disasar (Bayat 2005: 894).

Terlepas dari Islam sebagai ideologi, secara umum terdapat dua interpretasi yang berusaha diciptakan untuk memahami pergerakan politik agama di era modern. Kelompok tradisional menggambarkan Islam sebagai gerakan reaktif atas nilai-nilai modern yang lekat dengan budaya Barat, umumnya anti terhadap demokrasi. Kelompok ini hirau mengenai pentingnya revivalisme agama. Bagaimana agama diupayakan untuk berjaya layaknya pencapaian di era sebelumnya dan pengidentifikasian diri melalui gambaran di masa lalu mengenai kelahiran agama yang bersifat "quasi-religious". Sementara itu interpretasi kedua memandang bahwa Islam adalah gerakan agama yang merupakan manifestasi atau reaksi terhadap posmodernitas. Gerakan sosial mewakili perbedaan, budaya, dan moralitas melawan sebuah modernisasi sekural yang diuniversalkan. Foucault mendeskripsikan Revolusi Iran sebagai revolusi pos-modern pertama dalam sejarah. Castells menanggapinya sebagai 'exclusion of the excluders by the excluded'. Esposito menjabarkannya sebagai permintaan atas identitas dan komunitas, serta keinginan untuk mendirikan tatanan bagi kelompok dalam kehidupan personal maupun sosial. Islamisme dalam pendekatan ini merupakan manifestasi pencarian kepastian dalam dunia yang tidak pasti (Bayat 2005:894). Perspektif kedua menjadi paparan yang kompatibel mengenai gerakan sosial Islam yang terjadi di era modern. Di kondisi global saat ini, banyak gerakan sosial sebelum Revolusi Timur Tengah muncul di bawah agenda-agenda pemimpin Islam seperti Abul-ala Mawdudi, Ayatollah Khomeini, Ali Shariati, Musa Sadre, Sayed Qutb, dan banyak lainnya.

Gerakan sosial dalam realitanya merupakan entitas yang begitu dinamis, terus bergerak dan mengalir. EP Thompson (dalam Bayat 2005:897) menjelaskan bahwa gerakan sosial bukanlah sebuah benda. Gerakan sosial merupakan proses dan harus dipelajari sebagai fenomena histori dalam jangkauan waktu tertentu. Naratif dari pergerakan mengandung proses yang menawarkan ide komprehensif mengenai karakter-karakter tertentu. Seseorang tidak dapat menghiraukan Islamisme Iran tanpa memperhatikan aspek historis yang terjadi. Karenanya, penting untuk memahami fokus dan arah gerakan sosial karena perubahan yang terjadi bisa sangat cepat. Faktor-faktornya dapat berasal dari 
dalam maupun dari luar. Gerakan sosial juga dapat merubah langkah dan arahnya. Dinamika yang terkandung didalamnya dapat memngubah apa yang ditujukan ketika sebuah gerakan terbentuk untuk pertama kalinya. Hal ini tidak terjadi hanya karena tekanan eksternal, namun juga kontrol sosial dan faktor internasional yang mempengaruhi gerakan sosial. Mereka dapat berubah dalam keadaan tertentu dalam kondisi politik dan internasional yang berbeda pula (Bayat 2005:898).

\section{Hasil Penelitian dan Pembahasan}

\section{Arab Spring: Agama dan revolusi}

Apa yang terjadi di Arab, dari Tunisia hingga Mesir, dari Benghazi hingga Tripoli, telah menyita perhatian dunia karena tidak kunjung berhentinya gelombang protes yang berlangsung. Revolusi untuk menuntut hadirnya demokrasi, kebebasan ruang publik, dan tuntutan agar negara-negara yang telah lama berbentuk autokrasi tersebut bergabung dengan modernisme negara lain hingga kini berada dalam situasi yang rentan akan krisis dan konflik. Tanggal peristiwa bakar diri Bouazizi pada 17 Desember 2010 dianggap sebagai momentum awal Arab Spring yang kemudian tersebar hingga negara-negara Timur Tengah lainnya. Dalam beberapa jam dan hari, solidaritas bermunculan bagi demonstran yang terbunuh. Mereka dianggap meninggal sebagai Syuhada. Siaran berita Arab AlJazeera, menjadi media yang paling berpengaruh dan provokatif dengan menayangkan gambar bakar diri dan demonstrasi yang sedang terjadi. Protes dengan cepat segera tersebar ke ibu kota, bahkan hingga ke negara tetangga. Individu dari berbagai kalangan segera menjadi bagian dari gelombang protes: para pemuda, wanita dan pria, kelompok-kelompok agama, dan sebagainya. Kurang dari 2 bulan, 2 pemimpin autokrat di Timur Tengah digulingkan. Ben Ali turun dari kursi kepemimpinan Tunisia pada 14 Januari 2011 dan pempimpin Mesir Husni Mubarak menyusul 1 bulan kemudian, pada 11 Februari 2011 (Rosiny 2012:2).

Revolusi berjalan menyertakan partisipasi berbagai kelompok dengan latar belakang yang berbeda. Tidak heran jika banyak yang mengatakan bahwa Arab Spring adalah gerakan yang sepenuhnya sekuler. Gerakan massa digerakkan tidak hanya untuk menentang rezim yang berkuasa, namun juga untuk menentang ekstrimisme ideologi. Knickmeyer (dalam Hoffman \& Jamal 2013:2) menyatakan bahwa, "Tidak seperti kelompok-kelompok Arab yang dicurigai pada umumnya, seperti kelompok yang menumbuhkan jenggot atau gerakan kiri yang masih muda, tapi penggerak utama Arab Spring adalah kurangnya kesempatan ekonomi yang tersedia pada rakyat Arab, yang bersedia melawan sekalipun menyadari besarnya risiko yang dihadapi." Houeihed dan Warren juga menyatakan bahwa "Arab Spring bukanlah Islamic Spring. Pemicu utamanya bukanlah agama, melainkan ekspresi kemarahan atas korupsi yang dilakukan para elit, ketimpangan ekonomi, meluasnya ketidakadilan sosial, dan para pemimpin diktator."

Perlu dipahami bahwa dalam proses revolusi, budaya Keislaman serta Islamisme tidak dapat dilepaskan dari revolusi yang sedang terjadi. Seorang ahli Timur Tengah benama Jane Kinnimont menyatakan bahwa keberagaman dapat berada dalam satu gerakan Islamis dengan menemukan inspirasi, nilai, serta legitimasi yang diambil dari ajaran Islam (Hughes 2013). Di Mesir, Ikhwanul Muslimin merupakan kelompok yang memenangkan pemilu tahun 2011. Kelompok ini terkenal dengan slogan "Islam adalah Solusi," mengindikasikan bahwa Islamisme menjadi nadi dalam gerakan sosial politik yang dilakukan. Hingga 2 tahun Arab Spring terjadi, Hashemi (2013) menyatakan bahwa agama tidaklah terlepaskan dari politik bagi kelompok Muslim yang sedang dalam perjalanannya menuju demokrasi. Peranan partai politik dan intelektual agama sangat penting dalam demokratisasi tiap negara, terutama karena kombinasi antara politik dan standar universal mengenai hak asasi manusia, serta tuntutan atas demokrasi modern.

Lynch (2012 dalam Hoffman \& Jamal 2013:3) menyatakan bahwa hari Jumat (sebagai hari umat Muslim) menjadi "hari kemarahan" (days of rage) di Mesir dan banyak tempat lain karena pengorganisasian massa dilaksanakan selama Shalat Jumat. Masjid menjadi penghubung para demonstran dan menjadi pusat logistik dan persiapan bagi para demonstran, melahirkan istilah yang 
dikenal dengan "dari Masjid ke Lapangan". Hari Jumat yang biasa digunakan umat Muslim untuk beribadah telah berubah menjadi momen politik yang penting. Maskarakat berkumpul dari seluruh kota untuk menunjukkan solidaritas melalui demonstrasi. Dalam ibadah Jumat selalu terdapat sesi ceramah yang juga mendiskusikan isu-isu sosial, politik, pendidikan, seiringan dengan materi-materi agama. Masjid tidak lagi sebagai tempat peribadatan, namun juga menjadi kongres bagi kaum muslim untuk bertemu seminggu sekali dan mendiskusikan persoalan publik.

Inilah yang terjadi di Mesir pada 28 Januari 2011, sebagai revolusi Jumat pertama yang menandai 'keikutsertaan' Mesir atas revolusi. Lapangan Tahrir segera dipenuhi massa setelah ibadah Jumat selesai, dan protes melawan Mubarak dilakukan sejak saat itu (Mackay 2011). Masjid dan Ibadah Jumat menjadi modal sosial yang menghadirkan kepercayaan para pengikutnya untuk kemudian menyelenggarakan aksi bersama. Perubahan makna ibadah Jumat dari yang sebelumnya hanya sebatas ibadah, kemudian berubah menjadi kekuatan simbolik revolusi menandakan bahwa pelaksanaan praktik ibadah menjadi salah satu cara menjalani 'perlawanan'. Ribuan orang saling bersatu dan membentuk solidaritas sehingga memberi kekuatan bagi lainnya. Dilihat dari sisi strategi, pemilihan satu hari simbolik merupakan upaya untuk menarik atensi dan memfokuskan perlawanan selama satu hari dalam seminggu. Sulit untuk menjalankan protes dengan jumlah massa yang begitu besar sepanjang minggu. Maka dipilih 1 hari, yang merupakan hari pendek dan diketahui semua orang untuk memfokuskan perhatian secara total dalam satu hari tersebut.

\section{Menyandingkan Islam dan demokrasi}

Bagaimana kentalnya nilai Islam dihadirkan dalam gerakan sosial menghadirkan pertanyaan mengenai masa depan demokrasi yang dibawa oleh masyarakat sipil global. Samuel P. Huntington berarumen bahwa agama, terutama Islam, memberikan batasan pada demokratisasi. Pada tahun 1993, sejarawan Timur Tengah Lewis berusaha menjawab pertanyaan-pertanyaan mengenai Islam dan demokrasi liberal. Dia mempertanyakan, dapatkah demokrasi bekerja dalam masyarakat yang terinspirasi oleh kepercayaan, pengalaman, serta tradisi Islam? Penelitiannya menawarkan beberapa kesimpulan bahwa prospek bagi demokrasi di Timur Tengah tidaklah baik, dan ketika ditinjau dari perspektif politik, Islam menawarkan prospek terburuk terhadap demokrasi liberal (Lewis dalam Cook \& Stathis 2012:178). Beberapa atribut dalam Islam menghadirkan variabel kompleks terhadap demokrasi, terutama dalam masa transisi seperti yang terjadi di Arab. Agama dapat menjadi motivasi dalam hidup seorang individu. Bagi kaum Muslim, Islam lebih merupakan filosofi moral, sistem kepercayaan, atau perintah spiritual: Islam adalah pedoman yang lengkap dan menyeluruh bagi penganutnya (Geertz dalam Cook \& Stathis 2012:179). Di Timur Tengah, Islam menempati posisi istimewa sebagai sintetis antara individu, kelompok, agama dan politik, serta kehidupan holistik manusia. Praktik-praktik agama dan interaksi sosial hampir-hampir tidak dibedakan. Dalam kondisi negara Islam ideal, otoritas politik haruslah berdasarkan hukum Tuhan, bukan dalam bentuk teokrasi atau autokrasi yang memberikan kedaulatan pada elit pemerintah. Dalam skala minimum, negara harus memberikan perlindungan kepada Muslim untuk melaksanakan paktik ibadah. Bentuk inilah yang dilihat sebagai model negara ideal.

Situasi ini sering menjadi klaim bahwa Islam tidaklah selaras dengan demokrasi, dan gerakan yang terjadi di Arab tidak akan mudah terselesaikan karena persoalan mendasar ini. Namun fenomena Arab Spring menunjukkan bahwa menghadirkan demokrasi menjadi teramat penting untuk menciptakan pembangunan dan menghilangkan ketimpangan. Mendirikan demokrasi sudah tentu merupakan sebuah prosesi kompleks, terutama bagi negara yang belum pernah mengenal demokrasi sebelumnya. Bagi negara-negara Arab, demokrasi tentunya merupakan konsep yang abstrak. Selama lebih dari 40 tahun, Irak, Mesir, Tunisia, Libya, Yaman, telah hidup dibawah sistem otoriter. Namun perlu dipahami bahwa sekalipun Islam sering dikontraskan dengan demokrasi, sejatinya tidak ada kontradiksi inheren mengenai keduanya (Cook \& Stathis 2013:177). Islam dan demokrasi bukan tidak mungkin untuk disandingkan selama memenuhi prinsip dasar yang diperlukan yakni dengan meletakkan Islam sebagai dasar hukum dan agama nasional, namun tidak menciptakan hukum yang kontradiktif dengan prinsip-prinsip demokrasi (Cook \& Stahis 2013, 183). 
Selama masa pemilihan presiden di Mesir, Ikhwanul Muslimin mengatakan bahwa Wanita memiliki hak untuk menempati segala posisi kecuali dalam urusan kepresidenan. Sikap ini diambil sebagai penghargaan hak perempuan, namun tidak bertentangan dengan hukum Islam (Tashijan 2013). Hal ini berarti bahwa Islam sebagai teologi tidaklah berubah, namun keagamaannya berubah (Roy 2012:10). Keagamaan ini, baik liberal atau tidak, nyatanya kompatibel dengan demokrasi karena demokrasi yang dituntut hadir dalam sistem pemerintahan mengaitkan kepercayaan personal dari tradisi, identitas kolektif, dan otoritas eksternal. Pada demonstran Muslim yang kebanyakan masih berusia muda menemukan bahwa mereka dapat menyuarakan aspirasi mereka dengan bergabung dalam kelompok kecil (peer group) atau mengunakan internet sebagai media. Mereka mengkritisi budaya Islam yang dibawa orang tua mereka dan mencoba mengkonstruksi Islam dalam nuansa keagamaan yang baru.

Arab Spring menunjukkan bahwa bagi banyak kaum Muslim, demokrasi adalah jalan yang pantas untuk menciptakan bentuk negara ideal. Tunisia dan Mesir, merupakan 2 negara yang telah menjatuhkan pemimpin diktatornya, Ben Ali dan Husni Mubarak. Kedua negara juga telah menggelar pemilu, bahkan Mesir telah 2 kali menjalankan pemilu yakni pada tahun 2011 dan 2013. Tunisia menjadi negara pertama yang menghadapi demokrasi dengan terpilihnya presiden Habib Bourgiba. Bourgiba secara politik membatasi gerak politik kemiliteran, mendukung gerakan pekerja Tunisia, dan menjalankan visi politik sekular (Sorenson 2011:31-2). Benar jika terdapat hal-hal yang tidak bisa dinegosiasikan dalam Islam, namun pemisahan antara agama dengan pemerintahan menjadi agenda besar dalam Arab Spring. Revolusi tahun 2011 tidaklah sama dengan revolusi yang terjadi di Iran tahun 1979 yang menjadikan agama sebagai dasar dan tujuan revolusi. Berbeda dengan Ayatollah Komeini di Iran, Mesir dan Tunisia bukanlah tempat untuk menghadirkan Islam sebagai justifikasi tindakan-tindakan tertentu. Agama menjadi hal yang plural dan terbuka atas demokrasi.

Arab Spring menjadi fase yang menunjukkan bagaimana Islam menemukan bentuk barunya dalam arena politik. Hal ini bukan berarti Islamisme hilang. Gelombang protes yang terjadi berkontribusi pada terciptanya diversifikasi agama yang meletakkan para Islamis dalam satu set aktor agama diantara lainnya (Roy 2012:13). Mesir dan Tunisia tidak menjalani revolusi yang menjatuhkan dua diktatornya tanpa menyusun pengganti. Pemilu telah dilaksanakan dan perlemen telah diciptakan. Gerakan baru ini tidak mudah untuk dirubah karena nuansa protes yang masih tersisa dan masih hadir dalam upaya kedua negara membangun sistem negaranya yang baru. Seperti yang telah terjadi di Afghanistan dan Irak, gerakan Islam dari berbagai kawasan akan terkonsentrasi dan beroperasi dalam suatu arena yang seharusnya demokratis namun tidak menciptakan demokrasi dan legitimasi di mata masyarakat. Pemilu di Tunisia dan Mesir pada tahun 2011 telah menunjukkan bahwa tidak ada partai politik Islam yang dapat memonopoli ekspresi 'Islam' dalam politik. Pada umumnya, gerakan Islamis di Timur Tengah telah mengambil satu langkah lebih maju pada pemahaman mengenai konsep demokrasi dalam diskursus ideologi mereka (Dalacoura dalam Chamki 2013:4). Islam yang baru mengombinasikan modernisme teknokratik dan nilai-nilai konservatif dan Arab Spring mentransformasikan Islam dalam nilai-nilai yang lebih universal.

\section{Prospek demokrasi yang dibawa oleh Arab Spring}

Ketika gerakan masyarakat sipil global di Timur Tengah menuntut hadirnya demokrasi dengan berbagai pertaruhan, pertanyaan yang perlu dijawab selanjutnya adalah, jika demokrasi kemudian hadir dalam sistem pemerintaha negara-negara tersebut, apakah ia akan bertahan, dan bagaimana prospeknya di masa mendatang? Satu hal yang perlu dipahami adalah sekalipun Mubarak, Ben Ali, dan pemimpin lainnya dijatuhkan dari pucuk pemerintahan, demokrasi memerlukan waktu untuk tumbuh (Sorensen 2011:33). Jack Goldstone menyatakan bahwa sekalipun melalui revolusi yang damai, pada umumnya diperlukan separuh dekade agar sebuah rezim dapat berkonsolidasi dengan masyarakat secara stabil. Demokrasi merupakan sebuah sistem yang memerlukan 'biaya' besar dalam pembangunannya. Sistem demokrasi di Barat dikarakteristikkan dengan adanya: pemisahan kekuasaan, pemilu yang bebas, kebebasan warga sipil, hukum, serta penghargaan atas hak asasi manusia seperti kepemilikan pribadi, kebebasan berpendapat, serta toleransi beragama. Prinsip ini 
merupakan nilai yang sepenuhnya baru bagi negara-negara Timur Tengah. Negara-negara Arab sedang dalam proses menuju pemenuhan prinsip-prinsip demokrasi dalam sistem pemerintahannya. Tentunya jalan untuk menghadirkan demokrasi di kawasan tersebut tidaklah mudah.

Terlepas dari upaya kelompok masyarakat, upaya transfer kekuasaan dari elit pemimpin lama pada penggantinya sangat terbuka oleh ancaman ganguan, seperti yang terlihat di Tunisia dan Mesir. Aktoraktor dalam rezim lama masih hadir dan menjadikan transisi sebagai proses yang kian kompleks. Menurunkan diktator adalah hal yang sederhana, namun memerangi sistem politik yang korup, penuh dengan nepotisme dan patronase merupakan tantangan yang lebih besar. Diperlukan bertahun-tahun sebelum aktor pemerintah dapat menjadi satu-satunya aktor yang dilegitimasi. Sebelum itu, masyarakat sipil masih menjadi pengawas sekaligus juri yang menilai kinerja pemerintah (Hashemi 2012:219). Selain itu, upaya sekularisasi politik menjadi agenda besar yang belumlah selesai. Sekalipun telah dibahas mengenai bagaimana Islam bertransformasi sehingga lebih fleksibel terhadap demokrasi, namun menegosiasikan peranan normatif agama dalam politik adalah proses yang rumit dan rentan akan konflik. Alasannya adalah karena agama merupakan subjek yang sifatnya emosional dan sensitif serta berhubungan langsung dengan isu personal dan identitas kelompok. Beragamnya kelompok agama dalam masyarakat menciptakan pemikiran yang berbeda pula mengenai bagaimana agama seharusnya dipraktikkan dalam kehidupan politik. Menjalankannya secara demokratis akan menghabiskan banyak waktu dan rawan akan konflik (Hashemi 2012:219-20).

Namun demikian, tidak bijaksana untuk mengatakan bahwa prospek demokrasi dalam negara Muslim tidaklah cerah. Islam dan budaya Islam tidak mengandung hambatan tertentu atas demokrasi. Arab Spring justru menunjukkan bahwa terdapat sinergi antara keduanya yang dapat menghasilkan akomodasi. Apa yang terjadi di dunia Arab menunjukkan hadirnya kebutuhan akan ruang publik dan penghargaan diri masyarakat untuk turut dapat berpartisipasi dalam politik. Dengan kata lain, gerakan sosial dalam Arab Spring menghadirkan prospek yang lebih baik mengenai demokrasi di tempat yang tidak pernah mengenal demokrasi sebelumnya.

\section{Simpulan}

Arab Spring bukanlah gerakan Islam. Pemicu revolusi bukan karena urusan keagamaan, demonstran yang bergabung tidaklah seratus persen kaum muslim, dan isu yang dituntut tidak berkaitan dengan kehidupan beragama masyarakat, namun Islam baik nilai atau praktik ibadahnya, tidak dapat dipisahkan dalam pengorganisasian massa selama revolusi terjadi. Masjid menjadi 'pivot area' yang menyediakan kebutuhan-kebutuhan demonstran dan massa digerakkan selepas ibadah Jumat menjadi srategi yang dipilih gerakan sosial ini, selain itu kesamaan identitas, terlebih identitas agama, menyediakan modal tersendiri bagi demonstran untuk membangun kepercayaan dan solidaritas selama turun ke jalan dan menyuarakan tuntutannya terhadap pemerintah. Hadirnya Islam dalam menggambarkan ekspresi politik dan sosial menunjukkan bahwa Islamisme merupakan cara yang tidak terpisahkan bagi gerakan masyarakat sipil global dalam Arab Spring untuk mencapai tujuan politik mereka.

Arab Spring juga menjadi sebuah fenomena yang 'secara paksa' membawa demokrasi ke dunia Arab yang selama berdekade sebelumnya pada umumnya menerapkan sistem autokrasi. Pandangan pesimistis terus bermunculan mengingat hingga saat ini pergolakan masih terjadi, namun perlu disadari bahwa demokrasi merupakan proses yang tidak sebentar dan tidak pernah sepenuhnya selesai. Masyarakat dapat menyuarakan tuntutannya, wanita diakui hak-hak nya, hukum dan konstitusi sebagai dasar negara, menunjukkan bahwa meskipun masih jauh, ada sistem yang berusaha dibangun dengan berlandaskan demokrasi di Timur Tengah. Revolusi juga menunjukkan bahwa Islam mampu bertransformasi dalam arena politik modern dan menunjukkan pemisahan antara Islam sebagai kepercayaan dan Islam sebagai keagamaan. Ketika dimaknai sebagai kepercayaan, maka Islam bersifat teologis dan statis, namun keagamaannya menunjukkan dinamika ketika disandingkan dengan demokrasi, yang selama ini kerap diantitesiskan terhadap Islam.

Kedepan, jalan yang ditempuh negara-negara yang mengalami revolusi tidak akan mudah. Diperlukan waktu yang panjang dan biaya yang besar untuk mengembalikan stabilitas yang lama dalam sistem 
yang baru, namun perlu dicatat bahwa tanpa gerakan masyarakat untuk mengawali revolusi, demokrasi muda dalam level ini mungkin tidak akan pernah dicapai. Masa depan demokrasi dan perananannya untuk menciptakan perubahan memang tidak akan pernah menjadi suatu barang pasti. Apa yang terjadi selanjutnya memerlukan pengkajian lebih lanjut, namun menjadi pertanyaan besar yang menarik untu dijawab dan melengkapi studi tentang masyarakat sipil global.

\section{Daftar Pustaka}

Bayat A (2005) Islamism and social movement theory. Thirld World Quarterly 6 (26):891-908.

Chamki T (2013) Neo-Islamism post Arab Spring. Australian Political Studies Association Annual Conference 2013, Murdoch University.

Cook BJ \& Michael S (2012) Democracy and Islam: Promises and perils for the arab spring protests. Journal of Global Responsibility 3 (2):175-186.

Hassan H (2012) Islam, SMOs, and the srab spring: A new perspective on social movements in the Middle East. Thesis.

Hashemi N (2013) The Arab Spring two years on: Reflections on dignity, democracy, and devotion. Ethics \& International Affairs 27 (2):207-221.

Hoffman M \& Jamal A (2013) Religion in the Arab Spring: Between two comepting narratives.

Hughes OM (2013) Is the Arab Spring a 'clash of civilisations'? Global Politics 22 (4).

Mackay M (2011) Prayer and politics: How friday became Middle East's day of protest. [Diakses 8 Juni 2014]. http://edition.cnn.com/2011/WORLD/meast/06/17/friday.middle.east.protests/.

Rosiny S (2012) The Arab Spring, triggers, dynamics, and prospects. GIGA Focus Number 1.

Roy O (2012) The transformastion of the Arab world. Journal of Democracy 23 (3):5-18.

Sorenson DS (2011) Transitions in the Arab world: Spring or fall? Strategic Studies Quarterly.

Tashijan Y (2013) The fruits of "Arab Spring": Islamism, anarchism, \& feminism. Strategic Outlook. 